thick probe, and evidently of old formation. No communication existed between the uterine cavity and that of the abscess. The os and cervix uteri did not present any evidence of malignant disease. The Fallopian tubes and ovaries were adherent to the uterus, and could with difficulty be distinguished. The uterus had never been impregnated._Lancet, Jan. 28, 1843.

\section{DISLOCATION OF THE KNEE.}

TO THE EDITORS OF THE PROVIYCIAL MEDICAL JOURNAL.

Grntlexen,-My attention was drawn a short time since to a case of complete dislocation at the knee-joint, reported in the "London Medical Gazette" for the 16th ult. by Mr. Adams, in which he says, "the only unequivocal case which he knows of as having been reported in this country, is the one related by Mr. Toogood in your Journal for June, 1842 ;" and upon reference to the Number in question, I find Mr. Toogood says, "Sir Astley Cooper had never met with a case of dislocation at the knee, nor has any surgegn of his acquaintance connected with the London or provincial hospitals, neither does he remember to have read of such a case. Now, Gentlemen, the object of this communication is merely to refer the two above-named gentlemen-viz, Mr. Adams and $\mathrm{Mr}$. Toogood, to a case reported by me, and published in the "Medical Gazette" for May 14, 1836. Hoping you will be able to find room in a corner of your valuable Journal for this note,

I remain,

Your obedient Servant, T. Brittain, Surgeon.

Chester, Jan. 20, 1843.

\section{NOTE FROM MR. GARDNER.}

Mr. Gardner begs to say that he never saw or hea rd of the paper in the " Gazette Médicale," referred to by the reviewer of his pamphlet; and he requests the editors of the "Provincial Medical Gazette" (?) to insert this statement.

49, Great Portland Street,

Jan. 28, 1843.

\section{$\Longrightarrow$ \\ OBITUARY. \\ (From a Correspondent.)}

It is with much regret that we have to record the lamented death of Mr. Baynham, of Birmingham, surgeon. The life of this greatly respected gentleman terminated on Saturday, January 28 , after an illness of a few weeks' duration. In his death his family, the profession, and the public have sustained a severe loss. Mr. Baynham's mind, naturally acute, early made choice of the medical profession for its pursuit, and the zeal with which he commenced its studies continued unabatedly to animate him in practice. His unwearied diligence as a pathologist placed him by the consent of his professional brethren in a high rank; his love of facts, which is synonymous with love of truth, stimulated him to industry as a collector of them, whilst it rendered him extremely cautious in deducing the legitimate conclusions. This rare and interesting peculiarity will perhaps account for the extreme reluctance he manifested to give the result of his observations to the public. He was induced, however, to publish two valuable papers, one appeared in the "Midland Medical and Surgical Reporter," November, 1831, vol. III, entitled "Cases of Anourism "; and the other in the thirty-third volume of the " Edinburgh Medical and Surgical Journal," entitled " A Case of Retroverted Uterus, treated by puncture of that organ; with remarks on the circumstances which indicate the employment of that operation."

He had also prepared with great care and industry some statistical tables, which he thought might prove a useful contribution to medical science. The construction of these tables afforded agreeable occupation to a mind of restless activity and great exactness, qualities as favorable to this laborious and usually onerous pursuit, as the offices he occupied in some of the most important medical institutions were calculated to supply the necessary data upon which they were formed. Nearly twenty-seven years he was efficiently connected with the Birmingham General Dispensary, and fifteen years he was one of the surgeons to the Town Infirmary, and the incumbent duties devolving on him he ever fulfilled with exemplary fidelity.

\section{PROMOTIONS AND APPOINTMENTS. NAVAL.}

Surgeon-Edward Davis to the Blazer.

Assistant-surgeons-M. J. West to the Lily; John Jack to the Thunderer.

\section{ROYAL COLLEGE OF SURGEONS IN LONDON.}

Members admitted Friday, Jamuary 27, 1843.

C. Hithington, H. J. Preston, T. H. Benfield, A. Cartwright, L. Byles, J. Prowse, S. Singleton, T. Young, J. R. Lewer, T. Spencer, D. Coulter, C. H. Perry.

\section{TO CORRESPONDENTS.}

4 Medical Officer, Bradninch.-The poor-law commissioners have not issued any medical regulations since March, 1842.

The spirited letter of a barrister on phreno-mesmerism in our next.

We have not been able to find room for the report of the meeting of the Ethnological Society this week. The communication from Harry Larke, Esq., Whitechurch, Salop, has been received. If the case be authentic we shall publish it; but both christian and surname sound curiously.

JOURNALS AND BOOKS FOR REVIEW TO BB FORWARDED (CARRIAGE PAID), TO THE PUBLISHER, 356, gTRAND. LETTERS AND COMMUNICATIONB TO DR. HENNIS GREEN, 58, YARGARET STREET, CAVENDISH SQUARE, LONDON. 